\title{
The cost of smoking in California, 1993
}

\author{
Wendy Max, Dorothy P Rice
}

\begin{abstract}
The aim of the study was to develop estimates of the economic impact of smoking in each of California's 58 counties. Estimates are presented in 1993 dollars. Three measures of the economic impact of smoking were estimated. Direct cost represents the amount spent on hospital admissions, physician services, nursinghomecare, medications, and other services used due to smokingrelated illness. Morbidity cost is the value of lost productivity resulting from smoking-related loss of work days and days not spent in other productive activity. Mortality loss results from premature death due to smoking-related illness and represents the value of productivity loss. The methodology for estimating cost involved three steps. First the smoking attributable fraction (SAF), that is, the proportion of cases or deaths that results from smoking, was estimated for each region of California for each smoking related disease. Second, the SAF was applied to the number of deaths, days lost from work or productive activity (disability), or health care expenditures. Finally, smoking related deaths or disability were valued using the human capital approach. The total cost of smoking in California was estimated to be $\$ 10.0$ billion, amounting to $\$ 314$ per Californian and $\$ 2014$ per smoker.
\end{abstract}

(Tobacco Control 1995; 4 (suppl 1): S39-S46) Keywords: smoking costs; direct costs; morbidity costs; mortality costs; methods of cost estimation

\section{Introduction}

Cigarette smoking is a major cause of illness, disability, and premature death in California and in the United States. The health hazard of cigarette smoking has been well documented. More than 25 years ago, public interest and scientific debate prompted the Surgeon General of the Public Health Service to appoint an Advisory Committee on Smoking and Health to study the effect of smoking on the health of the US population. Since the landmark report of the Committee, published in $1964,{ }^{1}$ dramatic changes have occurred in the scientific knowledge base of the health hazards of smoking, in the public's knowledge of the dangers of smoking, and in the use of tobacco products.

Although there has been a substantial decline in smoking in recent years, $23 \%$ of men and $17 \%$ of women in California are current smokers. ${ }^{2}$ Many more people are former smokers. One way to document and assess the effect of smoking on the State is to translate into economic terms the human suffering, illness, premature mortality, and productivity loss caused by smoking. Cost estimates of smoking translate the adverse health effect of smoking into dollar terms, the universal language of decision makers and the policy arena. These estimates can be used to: (1) define the impact of cigarette smoking on health care delivery and financing and on the productivity of the population; (2) provide a basis for evaluating economic interventions, such as increases in cigarette taxes and financial incentives for not smoking; (3) provide the basis for health policy and health planning relative to tobacco control initiatives; (4) provide important testimony before state and local legislative bodies in support of non-smoking laws; and (5) provide an economic framework for programme evaluation.

California has been in the forefront of the nation in the enactment of local ordinances to control smoking in the workplace, restaurants, and public places. As of 1994, 16 counties mandate $100 \%$ smoke-free workplaces, including restaurants, and two more exclude restaurants; 350 cities in California have enacted local ordinances to control smoking and tobacco sales in public settings. ${ }^{3}$ On 1 January 1995, a statewide law was enacted mandating smoke-free workplaces. The counties without ordinances need estimates of the economic burden of smoking to facilitate their efforts to limit smoking in public places in their jurisdictions.

This paper presents estimates of the economic cost of smoking for the state of California including estimates for each of the state's 58 counties. Estimates were originally made for 1989, and have been updated to reflect 1993 costs. Further details about the methodology and findings are contained in the original report. $^{4}$

PREVIOUS SMOKING COST ESTIMATES FOR CALIFORNIA

Several recent reports have estimated the economic cost of smoking for California. These reports relied heavily on the national smoking attributable cost estimation methods developed by Rice and her colleagues in their 1986 landmark report. ${ }^{5}$ First, Kaplan and Wright ${ }^{6}$ prepared a report entitled Health and economic impact of smoking : 1985. They estimated that the total burden of smoking to Californians in 1985 amounted to $\$ 7.1$ billion. Deaths due to smoking numbered 31072 , years of potential 
life lost (YPLL) to 80 years of age amounted to 310018 , and productivity losses totalled $\$ 2.3$ billion. Kaplan and Wright also presented mortality and hospital discharge rates for all smoking related diseases in each county in California. The total economic cost of smoking in each county was not estimated.

The second cost of smoking estimates for the state were reported in the recent US Department of Health and Human Services report to Congress on Smoking and health ${ }^{7}$ which reported the following statistics for the California in 1985: total cost of smoking amounted to $\$ 5.8$ billion, deaths due to smoking numbered 28533, and YPLL to life expectancy totalled 331415 .

Although both the reports described above used a similar approach for estimating the economic cost of smoking in California and the same relative risks of smoking associated diseases to estimate the number and cost of smoking related deaths, the results for the same year are significantly different. The number of deaths differs by 2539 , or $9 \%$, and costs by $\$ 1.3$ billion, or $23 \%$. The reasons for the significantly differing results between the two studies are that different estimating procedures were employed. Both studies used aggregate approaches to estimating costs, but there were major differences in these approaches.

The third study of the cost of smoking in California, conducted by the authors, ${ }^{4}$ reported total costs amounting to $\$ 7.6$ billion in 1989 , distributed as follows: direct costs $\$ 2.4$ billion, morbidity costs $\$ 860$ million, and mortality costs $\$ 4.4$ billion. Deaths attributed to smoking amounted to 42207 and YPLL to life expectancy totalled 642793 .

The fourth report, prepared by the California Chronic and Sentinel Diseases Surveillance Program of the California Department of Health Services ${ }^{8}$ estimated a total of 42177 deaths attributable to smoking in California in 1988, resulting in 416813 years of life lost before the age of 80 years, and total mortality costs of over $\$ 5.8$ billion. For the 58 counties in California, only deaths, years of life lost, and resulting productivity losses were estimated.

The current study systematically develops detailed estimates for 1993 for each component of cost and employs the most recent applicable and reliable data available that are unique to California.

\section{Methodology}

The adverse health effect of smoking imposes an enormous economic burden on society, encompassing the costs associated with the use of medical resources and the value of losses in productivity due to illness and premature death. The cost of smoking in California includes three components: direct, morbidity, and mortality costs. The direct cost is comprised of payments, including expenditures for hospital and nursing home care, physician and other professional services, and drugs. The morbidity cost is the value of productivity lost by persons unable to perform their usual activities or unable to perform them at full effectiveness due to illness resulting from smoking. The mortality cost is the value of productivity lost due to premature death resulting from smoking-attributable disease.

\section{PREVALENCE $v$ INCIDENCE BASED APPROACH}

The prevalence based approach is used to estimate the cost of smoking in California. This method provides an estimate of the direct and indirect economic toll incurred during 1993 as a result of the prevalence of illness and the number of deaths due to smoking in that year. That is, the cumulative impact of smoking on health is considered. An alternative approach, the incidence-based approach, estimates the lifetime costs of smokers. Because state policy decisions are based on the immediate impact on smoking-related costs, the prevalence approach is used for this study. The incidence approach would be appropriate if one were comparing smokers and nonsmokers across their lifetimes.

\section{VALUING LIFE}

Economists generally employ two methods of valuing human life. One is the human capital approach, refined by Rice $^{9}$ and her colleagues. ${ }^{10}$ The second is the willingness-to-pay approach, first proposed by Schelling ${ }^{11}$ and Mishan. ${ }^{12}$ In the human capital approach, a person is seen as producing a stream of output that is valued at market earnings and the value of life is the discounted future earnings stream. Morbidity and mortality destroys labour, a valuable economic resource, by causing persons to lose time and effectiveness from work and other productive activities, forcing them out of the labour force completely, or bringing about premature death. Disease thus creates an undeniable loss to individuals and society, and it is this loss that the human capital approach attempts to measure. ${ }^{13}$ This method has some disadvantages. Because it values life using market earnings, it yields low values for children and the retired elderly. It also undervalues life if labour market imperfections exist and wages do not reflect true abilities. In addition, psychosocial costs, such as pain and suffering, are components of the burden of illness omitted from the human capital computation of indirect costs.

The willingness-to-pay approach values life according to what individuals are willing to pay for a change that reduces the probability of illness or death. This method could be helpful in indicating how individuals value health and life, in deriving social preferences regarding public policy, and in assessing the burden of pain and suffering, which have an intangible quality not amenable to evaluation in terms of the monetary value of resources used or forgone. A review by Robinson ${ }^{14}$ makes a strong case that the willingness-to-pay method is a fundamentally "incorrect" method of valuing life for cost-effective public policy. Robinson concludes that it is subjective and 
suffers from circularity because the values placed by individuals on government health programmes are clearly influenced by those policies.

The human capital approach is still most often used in cost-benefit and cost-effectiveness analyses that seek to evaluate alternative demands for scarce health resources and promote economic rationality in health services policy, planning, and management. This approach is used in the current study of the cost of smoking in California.

INTERNALISED COSTS AND EXTERNALITIES

For policy purposes, it may be useful to know who bears the costs of smoking. Economists distinguish between costs that are internalised, that is, born by the smoker, and those that impose uncompensated burdens or externalities on others. Because data on payer source were not available for California, and because our purpose was to measure the total burden of smoking regardless of who bears this burden, we did not make this distinction.

\section{DISCOUNT RATE}

A discount rate is used to convert a stream of earnings into a present value equivalent. The rate used reflects the trade off between the value of a dollar today and a dollar tomorrow. The higher the discount rate, the lower the present value of a given stream of earnings. The calculation of the present value of lifetime earnings raises questions about the importance of discounting and choosing the appropriate discount rate. From the economist's viewpoint, the arithmetical sum of lifetime earnings overstates the present value of an individual. Determining the present value of the future earnings stream is the correct way to measure economic value over a period of time; discounting converts a stream of earnings into its present value. Economists agree that comparisons of streams of earnings over varying time spans should employ the process of discounting and that benefits of public projects for which cost of illness estimates are used should be discounted at the social rate of time preference, which states society's preference for present versus future consumption. Unfortunately, the social rate of time preference is unobservable and the actual value is uncertain. ${ }^{13}$ Discount rates between 2 and $6 \%$ are commonly used today, reflecting the subjective judgement of the analyst. Our estimates employ a mid-range estimate of $4 \%$, with sensitivity analyses comparing the estimates resulting from using rates of $2 \%$ and $6 \%$.

\section{SAMMEC II}

Estimates of the cost of smoking were generated using the computer software package SAMMEC II - Smoking Attributable Mortality, Morbidity, and Economic Costs. ${ }^{15}$ SAMMEC operates within the framework of LOTUS 1-2-3 with input data provided for this study for California. The methodology of SAMMEC uses an epidemiological relative risk based approach to the estimation of prevalence costs. The estimates generated are limited by the specificity of the input data available for the region under study. The program was used to generate estimates for 18 regions in California. The regions consist of the 10 largest counties plus eight regions comprised of groups of the remaining 48 counties. The regional estimates were then disaggregated into 58 county estimates.

\section{SMOKING ATTRIBUTABLE FRACTIONS}

The estimation of the three measures of economic burden is based on a common methodology. It is first necessary to estimate the smoking attributable fraction (SAF) for each smoking related disease. The SAF is the proportion of cases or deaths that can be attributed to smoking. Two types of data are used in the calculation of the SAF : relative risk and the smoking prevalence rate. Relative risk is the ratio of rates of illness or death in the exposed population compared to the nonexposed population. The smoking prevalence rate is the percentage of smokers in the group under study, in this case California smokers. Current smoking rates for California are from a survey of cigarette smoking behaviours and attitudes among Californians conducted between June 1990 and July 1991 by the University of California, San Diego and Westat Corporation under contracts with the California Department of Health Services and the County of Los Angeles. ${ }^{2}$ Separate samples were drawn to be representative of each of the 10 counties in California with the largest population, and the remaining counties were grouped into eight regions with separate samples for each region. Smoking use rates for the eight regions were applied to each of the counties within the regions.

Given relative risk and smoking prevalence rates, the smoking attributable fraction is calculated using an adaptation of the standard epidemiological formula for attributable risk. ${ }^{16}$ That is,

$\mathrm{SAF}=\frac{\left[\left(\mathrm{p}_{0}+\mathrm{p}_{1}\left(\mathrm{RR}_{1}\right)+\mathrm{p}_{2}\left(\mathrm{RR}_{2}\right)\right]-1\right.}{\left[\left(\mathrm{p}_{0}+\mathrm{p}_{1}\left(\mathrm{RR}_{1}\right)+\mathrm{p}_{2}\left(\mathrm{RR}_{2}\right)\right]\right.}$

where

$\mathrm{p}_{0}=$ percentage of never-smokers in region

$\mathrm{p}_{1}=$ percentage of current smokers in region

$\mathrm{p}_{2}=$ percentage of former smokers in region

$\mathrm{RR}_{1}=$ relative risk for current smokers relative to never smokers

$\mathrm{RR}_{2}=$ relative risk for former smokers relative to never smokers

The SAF is then applied to the cost component being estimated to determine what proportion of costs can be attributed to smoking. Costs were updated to 1993 using the percent change in national health expenditures for direct costs, and the percent change in the index of hourly earnings for indirect costs. The estimation of each component is discussed next. 
DIRECT COST

The smoking attributable direct cost is the proportion of health care expenditures that results from smoking. Two measures of relative risks are estimated, based on 1987 National Health Interview Survey data: the relative rates of hospital admission and physician visits for current, former, and never-smokers. Only persons of 35 years and older with neoplasms, cardiovascular disease, and respiratory diseases were included. The relative rates of hospital admission were used to calculate the SAF for hospital care, nursing home care, and other professional services. The relative rates of physician visits were used to calculate the SAF for physician visits and medication costs. The SAF was then applied to state level expenditures.

\section{MORBIDITY COST}

The smoking attributable morbidity cost is the value of lost income and productivity for persons who are unable to work or participate in productive activities due to smoking related illness. Two morbidity indicators - work loss days and bed disability days - are used to estimate the SAF. Data from the 1987 National Health Interview Survey were used to estimate the work loss days per 100 currently employed persons and bed disability days per 100 persons keeping house for current, former, and neversmokers. Relative rates of disability for current smokers and former smokers compared with never-smokers were calculated. These relative risk rates were then used to calculate the SAF.

Because region level data on morbidity costs are not available, these two measures were next converted to a rate per 1000 persons, which was applied to region population to estimate total work loss and bed disability days (total disability days). Next, total disability days were multiplied by the SAF to obtain an estimate of smoking related disability days. Finally, smoking related disability days were multiplied by mean daily productivity losses, which consider both labour market earnings and an imputed value for housekeeping services.

MORTALITY COST

Estimating mortality cost consists of first determining which deaths are attributable to smoking related diseases, and then valuing the resulting loss of lives.

\section{Deaths attributed to smoking}

Deaths attributed to smoking are the proportion of total deaths that can be regarded as causally linked to smoking. The relative risks used for the calculation of the SAF are taken from the 25th Anniversary Report of the Surgeon General of the United States. ${ }^{17}$ SAMMEC includes relative risk estimates for 22 smoking related diseases of adults (that is, 35 years and over) and relative risk estimates for four perinatal conditions (that is, children under one year of age conditions). ${ }^{15}$ Also included are deaths from passive smoking and burns.

\section{Productivity losses}

Productivity losses are the current monetary value of future output lost due to premature death from smoking. If individuals had not died prematurely, they would have continued to be productive for a number of years. The estimated losses or value to society of all deaths is the product of the number of deaths attributed to smoking and the discounted value of an individual's earnings with sex and age taken into account. This method of derivation takes into consideration life expectancy for different age and sex groups, changing patterns of earnings at successive ages, varying labour force participation rates, imputed value for housekeeping services, and the appropriate discount rates to convert a stream of costs or benefits into its present worth.

\section{Results}

PREVALENCE

In 1992, 4.3 million Californians smoked. ${ }^{2}$ This includes 204000 adolescents aged 12 to 17: 93000 boys and 111000 girls. More men than women smoked (2398000 $v 1926000)$ and most adult smokers were aged 25-44 years. Over six million additional Californians were former smokers, who may continue to experience the health effects of smoking.

\section{TOTAL COST}

The total cost to California of the health effects of smoking in 1993 amounted to $\$ 10.0$ billion, the equivalent of $\$ 314$ per resident and $\$ 2014$ per smoker, as shown in table 1 . The direct costs represented $36 \%$ of the total, morbidity costs were $10 \%$, and mortality costs were $54 \%$.

The cost of smoking for males in 1993 was $\$ 7.0$ billion compared to $\$ 3.0$ billion for females, as shown in table 1 and in the figure. The higher costs for males reflect the fact that men are more likely to be current or former smokers, and that men are more likely to be in the labour market and have higher earnings. On a per smoker basis, the total cost for men is nearly twice the cost for women, and the health care costs alone are 1.7 times greater for men than for women.

\section{DIRECT COST}

The direct costs were $\$ 3.6$ billion, with more than two thirds of these direct costs $(70 \%)$ going for expenditure on hospital admissions. Smoking is responsible for 1 in 20 hospital dollars and 1 in 20 dollars spent on nursing home care in the state. While the direct costs for men were over twice that of women, smoking related expenditures per smoker were greater for women for physician services, nursing home care, and medications. This reflects the greater longevity of women and the fact that they tend to visit physicians more often. 
Table 1 Cost of smoking by type of cost and gender, California, 1993

\begin{tabular}{|c|c|c|c|c|}
\hline Type of cost and gender & $\begin{array}{l}\text { Amount } \\
\text { (thousands) }\end{array}$ & $\begin{array}{l}\text { Percent } \\
\text { distribution }\end{array}$ & $\begin{array}{l}\text { Per } \\
\text { resident }\end{array}$ & $\begin{array}{l}\text { Per } \\
\text { smoker }\end{array}$ \\
\hline $\begin{array}{l}\text { Total } \\
\text { Direct cost } \\
\text { Hospital } \\
\text { Physician } \\
\text { Nursing home } \\
\text { Medication } \\
\text { Other professional }\end{array}$ & $\begin{array}{r}\$ 9960844 \\
3584107 \\
2522226 \\
615241 \\
229874 \\
180354 \\
36412\end{array}$ & $\begin{array}{r}100.0 \\
36.0 \\
25.3 \\
6.2 \\
2.3 \\
1.8 \\
0.4\end{array}$ & $\begin{array}{r}\$ 313.80 \\
112.91 \\
79.46 \\
19.38 \\
7.24 \\
5.68 \\
1.15\end{array}$ & $\begin{array}{r}\$ 2014.00 \\
724.69 \\
509.97 \\
124.40 \\
46.47 \\
36.47 \\
7.37\end{array}$ \\
\hline $\begin{array}{c}\text { Indirect cost } \\
\text { Morbidity } \\
\text { Mortality }\end{array}$ & $\begin{array}{l}6376737 \\
1040673 \\
5336064\end{array}$ & $\begin{array}{l}64.0 \\
10.4 \\
53.6\end{array}$ & $\begin{array}{r}200.89 \\
32.78 \\
168.11\end{array}$ & $\begin{array}{r}1289.32 \\
210.42 \\
1078.90\end{array}$ \\
\hline $\begin{array}{l}\text { Men, Total } \\
\text { Direct cost } \\
\text { Hospital } \\
\text { Physician } \\
\text { Nursing home } \\
\text { Medication } \\
\text { Other professional }\end{array}$ & $\begin{array}{r}6984360 \\
2450906 \\
1951109 \\
293934 \\
101274 \\
83915 \\
20673\end{array}$ & $\begin{array}{r}100.0 \\
35.1 \\
27.9 \\
4.2 \\
1.5 \\
1.2 \\
0.3\end{array}$ & $\begin{array}{r}439.54 \\
154.24 \\
122.79 \\
18.50 \\
6.37 \\
5.28 \\
1.30\end{array}$ & $\begin{array}{r}2509 \\
880.51 \\
700.98 \\
105.60 \\
36.38 \\
30.14 \\
7.42\end{array}$ \\
\hline $\begin{array}{l}\text { Indirect cost } \\
\text { Morbidity } \\
\text { Mortality }\end{array}$ & $\begin{array}{r}4533455 \\
679457 \\
3853997\end{array}$ & $\begin{array}{r}64.9 \\
9.7 \\
55.2\end{array}$ & $\begin{array}{r}285.30 \\
42.76 \\
242.54\end{array}$ & $\begin{array}{r}1628.72 \\
244.11 \\
1384.62\end{array}$ \\
\hline Women, Total & 2976483 & 100.0 & 187.74 & 1376 \\
\hline $\begin{array}{l}\text { Direct cost } \\
\text { Hospital } \\
\text { Physician } \\
\text { Nursing home } \\
\text { Medication } \\
\text { Other professional }\end{array}$ & $\begin{array}{r}1133202 \\
571117 \\
321307 \\
128600 \\
96439 \\
15739\end{array}$ & $\begin{array}{r}38.1 \\
19.2 \\
10.8 \\
4.3 \\
3.2 \\
0.5\end{array}$ & $\begin{array}{r}71.48 \\
36.02 \\
20.27 \\
8.11 \\
6.08 \\
0.99\end{array}$ & $\begin{array}{r}524.05 \\
264.11 \\
148.59 \\
59.47 \\
44.60 \\
7.27\end{array}$ \\
\hline $\begin{array}{l}\text { Indirect cost } \\
\text { Morbidity } \\
\text { Mortality }\end{array}$ & $\begin{array}{r}1843282 \\
361216 \\
1482066\end{array}$ & $\begin{array}{l}61.9 \\
12.1 \\
49.8\end{array}$ & $\begin{array}{r}116.26 \\
22.78 \\
93.48\end{array}$ & $\begin{array}{l}852.42 \\
167.04 \\
685.38\end{array}$ \\
\hline
\end{tabular}

Note: Numbers may not add to total due to rounding.

* Discounted at $4 \%$.



MALES

\$6.984 billion

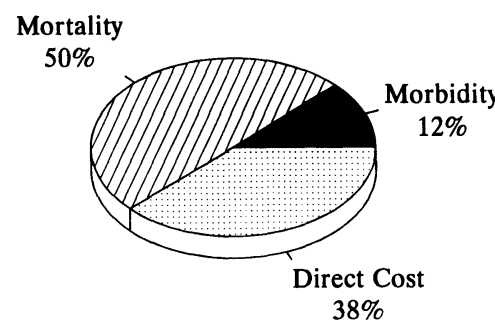

FEMALES

\$2.976 billion

TOTAL COST $=\$ 9.961$ billion

Figure 1 Cost of smoking by type of cost and gender, California 1993 (billions)

MORBIDITY COST

Morbidity costs of $\$ 1.0$ billion indicate that smokers lose many days from productive activities. Losses amounted to $\$ 244$ per male smoker and $\$ 167$ per female smoker.

\section{MORTALITY COSTS}

The value of lost productivity from smoking related deaths in 1993 dollars was $\$ 5.3$ billion, or $\$ 125830$ per death using a discount rate of $4 \%$. This amounts to $\$ 168$ for each resident of the state and $\$ 1079$ for each smoker. At a discount rate of $2 \%$, the values are $\$ 6.2$ billion or $\$ 149000$ per death; and at $6 \%$ the values are $\$ 4.6$ billion and $\$ 111000$ respectively. Fully $44 \%$ of the losses are from deaths due to cardiovascular diseases, followed by neoplasms $(40 \%)$, and respiratory disease $(13 \%)$.
COST BY COUNTY

Table 2 contains estimates of the total and per resident direct, morbidity, and mortality costs updated to 1993 for each of California's 58 counties. The total cost of nearly $\$ 10$ billion is distributed unequally among counties. The three counties that incur the greatest smoking related costs - Los Angeles, San Diego, and Orange - are all large populous southern California counties with relatively high smoking prevalence rates. They account for $45 \%$ of the state population, and nearly half of the state smoking costs, and Los Angeles County total costs are four times those of San Diego County, the second most costly county. At the other extreme, the counties that incurred the lowest costs (excluding statistically unreliable estimates) are sparsely populated mountain counties-Mariposa, Colusa, and Plumas counties. 
Table 2 Cost of smoking by California county, 1993

\begin{tabular}{|c|c|c|c|c|c|c|c|c|}
\hline \multirow[b]{2}{*}{ County } & \multirow[b]{2}{*}{ Total } & \multicolumn{3}{|c|}{ Total cost (\$thousands) } & \multicolumn{4}{|c|}{ Cost per resident $(\$)$} \\
\hline & & Direct & Morbidity & Mortality ${ }^{\star}$ & Total & Direct & Morbidity & Mortality \\
\hline California & 9960844 & 3584107 & 1040673 & 5336064 & 314 & 113 & 33 & 168 \\
\hline $\begin{array}{l}\text { Alameda } \\
\text { Alpinet } \\
\text { Amador } \\
\text { Butte } \\
\text { Calaveras }\end{array}$ & $\begin{array}{r}479272 \\
189 \\
11063 \\
66379 \\
13909\end{array}$ & $\begin{array}{r}158364 \\
122 \\
3676 \\
22222 \\
3930\end{array}$ & $\begin{array}{r}42998 \\
66 \\
1549 \\
7853 \\
1643\end{array}$ & $\begin{array}{r}277910 \\
1 \\
5838 \\
36304 \\
8336\end{array}$ & $\begin{array}{l}358 \\
157 \\
335 \\
336 \\
376\end{array}$ & $\begin{array}{l}118 \\
102 \\
111 \\
112 \\
106\end{array}$ & $\begin{array}{l}32 \\
55 \\
47 \\
40 \\
44\end{array}$ & $\begin{array}{r}208 \\
1 \\
177 \\
184 \\
225\end{array}$ \\
\hline $\begin{array}{l}\text { Colusa } \\
\text { Contra Costa } \\
\text { Del Norte } \\
\text { El Dorado } \\
\text { Fresno }\end{array}$ & $\begin{array}{r}7002 \\
242915 \\
9002 \\
34751 \\
206591\end{array}$ & $\begin{array}{r}1952 \\
75169 \\
2382 \\
12118 \\
78386\end{array}$ & $\begin{array}{r}692 \\
28756 \\
845 \\
5076 \\
21528\end{array}$ & $\begin{array}{r}4359 \\
138990 \\
5776 \\
17556 \\
106677\end{array}$ & $\begin{array}{l}398 \\
282 \\
316 \\
244 \\
279\end{array}$ & $\begin{array}{r}111 \\
87 \\
84 \\
85 \\
106\end{array}$ & $\begin{array}{l}39 \\
33 \\
30 \\
36 \\
29\end{array}$ & $\begin{array}{l}248 \\
161 \\
203 \\
123 \\
144\end{array}$ \\
\hline $\begin{array}{l}\text { Glenn } \\
\text { Humboldt } \\
\text { Imperial } \\
\text { Inyo } \\
\text { Kern }\end{array}$ & $\begin{array}{r}9396 \\
50338 \\
35536 \\
8834 \\
185100\end{array}$ & $\begin{array}{r}2537 \\
12413 \\
10351 \\
2446 \\
51905\end{array}$ & $\begin{array}{r}897 \\
4393 \\
3616 \\
855 \\
18135\end{array}$ & $\begin{array}{r}5962 \\
33532 \\
21568 \\
5534 \\
115060\end{array}$ & $\begin{array}{l}355 \\
398 \\
270 \\
470 \\
303\end{array}$ & $\begin{array}{r}96 \\
98 \\
79 \\
130 \\
85\end{array}$ & $\begin{array}{l}34 \\
35 \\
27 \\
45 \\
30\end{array}$ & $\begin{array}{l}225 \\
265 \\
164 \\
294 \\
188\end{array}$ \\
\hline $\begin{array}{l}\text { Kings } \\
\text { Lake } \\
\text { Lassen } \dagger \\
\text { Los Angeles } \\
\text { Madera }\end{array}$ & $\begin{array}{r}32669 \\
23206 \\
6299 \\
3111867 \\
30216\end{array}$ & $\begin{array}{r}8770 \\
6526 \\
2815 \\
1241010 \\
9690\end{array}$ & $\begin{array}{r}3065 \\
2309 \\
1002 \\
279748 \\
2657\end{array}$ & $\begin{array}{r}20834 \\
14371 \\
2482 \\
1591110 \\
17869\end{array}$ & $\begin{array}{l}290 \\
414 \\
215 \\
338 \\
289\end{array}$ & $\begin{array}{r}78 \\
117 \\
96 \\
135 \\
93\end{array}$ & $\begin{array}{l}27 \\
41 \\
34 \\
30 \\
25\end{array}$ & $\begin{array}{r}185 \\
257 \\
85 \\
173 \\
171\end{array}$ \\
\hline $\begin{array}{l}\text { Marin } \\
\text { Mariposa } \\
\text { Mendocino } \\
\text { Merced } \\
\text { Modoct }\end{array}$ & $\begin{array}{r}73987 \\
4670 \\
28483 \\
57357 \\
3544\end{array}$ & $\begin{array}{r}25497 \\
1538 \\
9087 \\
19787 \\
1163\end{array}$ & $\begin{array}{r}9940 \\
645 \\
3215 \\
5428 \\
412\end{array}$ & $\begin{array}{r}38550 \\
2487 \\
16181 \\
32143 \\
1969\end{array}$ & $\begin{array}{l}306 \\
288 \\
339 \\
293 \\
344\end{array}$ & $\begin{array}{r}106 \\
95 \\
108 \\
101 \\
113\end{array}$ & $\begin{array}{l}41 \\
40 \\
38 \\
28 \\
40\end{array}$ & $\begin{array}{l}160 \\
154 \\
192 \\
164 \\
191\end{array}$ \\
\hline $\begin{array}{l}\text { Monof } \\
\text { Monterey } \\
\text { Napa } \\
\text { Nevada } \\
\text { Orange }\end{array}$ & $\begin{array}{r}1992 \\
89982 \\
37189 \\
25194 \\
758892\end{array}$ & $\begin{array}{r}1071 \\
30109 \\
11454 \\
8561 \\
312023\end{array}$ & $\begin{array}{r}375 \\
10568 \\
4468 \\
3575 \\
74979\end{array}$ & $\begin{array}{r}546 \\
49305 \\
21267 \\
13057 \\
371890\end{array}$ & $\begin{array}{l}183 \\
238 \\
316 \\
293 \\
295\end{array}$ & $\begin{array}{r}98 \\
80 \\
97 \\
99 \\
121\end{array}$ & $\begin{array}{l}34 \\
28 \\
38 \\
42 \\
29\end{array}$ & $\begin{array}{c}50 \\
130 \\
181 \\
152 \\
144\end{array}$ \\
\hline $\begin{array}{l}\text { Placer } \\
\text { Plumas } \\
\text { Riverside } \\
\text { Sacramento } \\
\text { San Benito }\end{array}$ & $\begin{array}{r}54238 \\
7173 \\
399849 \\
393089 \\
10624\end{array}$ & $\begin{array}{r}16402 \\
2528 \\
117204 \\
151339 \\
3293\end{array}$ & $\begin{array}{r}6857 \\
896 \\
40462 \\
36981 \\
1159\end{array}$ & $\begin{array}{r}30980 \\
3749 \\
242184 \\
204769 \\
6172\end{array}$ & $\begin{array}{l}275 \\
338 \\
299 \\
349 \\
259\end{array}$ & $\begin{array}{r}83 \\
119 \\
88 \\
135 \\
80\end{array}$ & $\begin{array}{l}35 \\
42 \\
30 \\
33 \\
28\end{array}$ & $\begin{array}{l}157 \\
177 \\
181 \\
182 \\
151\end{array}$ \\
\hline $\begin{array}{l}\text { San Bernardino } \\
\text { San Diego } \\
\text { San Francisco } \\
\text { San Joaquin } \\
\text { San Luis Obispo }\end{array}$ & $\begin{array}{r}470239 \\
788658 \\
342444 \\
158011 \\
62818\end{array}$ & $\begin{array}{r}147318 \\
278470 \\
150644 \\
38732 \\
20897\end{array}$ & $\begin{array}{r}44974 \\
137759 \\
27942 \\
16189 \\
7116\end{array}$ & $\begin{array}{r}277948 \\
372429 \\
163857 \\
103090 \\
34806\end{array}$ & $\begin{array}{l}298 \\
296 \\
457 \\
304 \\
272\end{array}$ & $\begin{array}{r}93 \\
104 \\
201 \\
75 \\
90\end{array}$ & $\begin{array}{l}29 \\
52 \\
37 \\
31 \\
31\end{array}$ & $\begin{array}{l}176 \\
140 \\
219 \\
198 \\
151\end{array}$ \\
\hline $\begin{array}{l}\text { San Mateo } \\
\text { Santa Barbara } \\
\text { Santa Clara } \\
\text { Santa Cruz }\end{array}$ & $\begin{array}{r}196051 \\
95807 \\
408911 \\
63261\end{array}$ & $\begin{array}{r}60574 \\
33180 \\
157301 \\
22529\end{array}$ & $\begin{array}{r}23805 \\
11292 \\
46385 \\
7899\end{array}$ & $\begin{array}{r}111672 \\
51334 \\
205225 \\
32833\end{array}$ & $\begin{array}{l}287 \\
247 \\
260 \\
266\end{array}$ & $\begin{array}{r}89 \\
86 \\
100 \\
95\end{array}$ & $\begin{array}{l}35 \\
29 \\
29 \\
33\end{array}$ & $\begin{array}{l}164 \\
132 \\
130 \\
138\end{array}$ \\
\hline Shasta & 62852 & 16183 & 5722 & 40947 & 387 & 100 & 35 & 252 \\
\hline $\begin{array}{l}\text { Sierra† } \\
\text { Siskiyou } \\
\text { Solano } \\
\text { Sonoma } \\
\text { Stanislaus }\end{array}$ & $\begin{array}{r}1612 \\
19596 \\
102242 \\
122190 \\
137301\end{array}$ & $\begin{array}{r}355 \\
5222 \\
27132 \\
37884 \\
45284\end{array}$ & $\begin{array}{r}149 \\
1848 \\
10662 \\
14758 \\
12439\end{array}$ & $\begin{array}{r}1107 \\
12526 \\
64448 \\
69548 \\
79579\end{array}$ & $\begin{array}{l}474 \\
431 \\
274 \\
293 \\
334\end{array}$ & $\begin{array}{r}105 \\
115 \\
73 \\
91 \\
110\end{array}$ & $\begin{array}{l}44 \\
41 \\
29 \\
35 \\
30\end{array}$ & $\begin{array}{l}326 \\
275 \\
173 \\
167 \\
194\end{array}$ \\
\hline $\begin{array}{l}\text { Sutter } \\
\text { Tehama } \\
\text { Trinity } \\
\text { Tulare } \\
\text { Tuolumne }\end{array}$ & $\begin{array}{r}23235 \\
21420 \\
5483 \\
108611 \\
18774\end{array}$ & $\begin{array}{r}5545 \\
5637 \\
1629 \\
29808 \\
4961\end{array}$ & $\begin{array}{r}2314 \\
1993 \\
578 \\
10413 \\
2079\end{array}$ & $\begin{array}{r}15377 \\
13790 \\
3277 \\
68391 \\
11734\end{array}$ & $\begin{array}{l}322 \\
395 \\
403 \\
313 \\
356\end{array}$ & $\begin{array}{r}77 \\
104 \\
120 \\
86 \\
94\end{array}$ & $\begin{array}{l}32 \\
37 \\
42 \\
30 \\
39\end{array}$ & $\begin{array}{l}213 \\
254 \\
241 \\
197 \\
223\end{array}$ \\
\hline $\begin{array}{l}\text { Ventura } \\
\text { Yolo } \\
\text { Yuba }\end{array}$ & $\begin{array}{r}171195 \\
45770 \\
23565\end{array}$ & $\begin{array}{r}60191 \\
12362 \\
4430\end{array}$ & $\begin{array}{r}20490 \\
4374 \\
1852\end{array}$ & $\begin{array}{l}90514 \\
29034 \\
17282\end{array}$ & $\begin{array}{l}244 \\
306 \\
372\end{array}$ & $\begin{array}{l}86 \\
83 \\
70\end{array}$ & $\begin{array}{l}29 \\
29 \\
29\end{array}$ & $\begin{array}{l}129 \\
194 \\
273\end{array}$ \\
\hline
\end{tabular}

Note: Numbers may not add to total due to rounding.

$\star$
+ Discounted at $4 \%$.

Considerable variation in smoking cost per resident occurs (based on statistically reliable estimates) among the 58 counties in California, ranging from $\$ 470$ per resident in Inyo County to $\$ 238$ per resident in Monterey County.

LIMITATIONS OF THE DATA

While these estimates are based on the best available data for California, a number of limitations must be acknowledged. If smokers are less health conscious than other Californians, then other risk factors such as obesity and alcohol consumption may account for some of smokers' health care costs. Smoking behaviour needs to be modelled in more detail; ideally a measure of pack-years of exposure should be developed. Furthermore, socioeconomic status and access to health care should be considered. Scientists are only beginning to understand the full impact of exposure to secondhand smoke on health. While there are no datasets for California that permit one to incorporate all these factors into a more detailed model of smoking behaviour, better data do exist at the national level. In our ongoing analysis of the health effects of smoking in the USA, based on the National Medical Expenditure Survey, ${ }^{18}$ we found that after modelling the interrelationships among the factors discussed above, the cost of smoking is much greater than previously estimated. For example, national medical expenditures attributed to smoking comprised $7.1 \%$ of total 
personal health care spending; our comparable estimate for California is $5.1 \%$, indicating that the direct cost estimates presented here are understated. As better data become available for California, the estimates can be refined.

\section{Discussion}

While the prevalence of smoking has been declining over time, 4.3 million Californians still smoke. The health effects of smoking cost Californians nearly $\$ 10$ billion in 1993 or $\$ 314$ for each resident of the state. These estimates are conservative for several reasons. We have not taken into account property losses to fire caused by smoking, automobile accidents, or the non-health-sector costs, such as transportation to providers, and costs incurred by industry for environmental and safety investments. More importantly, we have used the human capital approach in this study rather than the willingness to pay approach which would yield much higher estimates for values of life. Based on 29 studies, Miller ${ }^{19}$ estimated that the willingness to pay to save one life ranged from $\$ 1.0$ million to $\$ 3.0$ million in 1985 , with a mean of $\$ 1.95$ million. In 1985 , the present value of lifetime earnings for males aged 25-29 amounted to $\$ 749695$ and for females aged $20-24$ it amounted to $\$ 578481$; the amounts were lower for all other age groups. ${ }^{20}$

Large county differentials exist in both total costs of smoking and cost per resident. Given the limited resources available for tobacco control policies, policy makers should target programmes to those counties where there is the greatest potential to reduce costs.

Several proposals have been put forward at the federal level to increase the tax on cigarettes in order to finance major health care reform. Proposition 99, which raised the tax per pack of cigarettes in California from 10 cents to 35 cents per pack on 1 January 1989 does not come close to taxing the full costs of smoking. If California smokers were to pay for the cost of health care related to smoking, the price of each pack of cigarettes would have to increase by $\$ 1.82$. If productivity losses were also included, the price per pack would rise by an additional $\$ 3.24$ to a total of $\$ 5.06$ per pack. If costs were born by smokers, each smoker would have to pay $\$ 2014$ per year, including $\$ 725$ in health care costs alone.

The question has been raised as to whether smokers are paying for their smoking habits and therefore should not be taxed further. Two recent studies compared medical costs of smokers with savings resulting from their shorter life expectancy. Hodgson ${ }^{21}$ concludes that on balance, "smokers incur higher expenditures for medical care over their lifetimes than never-smokers". Manning and colleagues used data from the National Health Interview Survey and the Rand Health Insurance Experiment to estimate the cost imposed by smokers on others, including increased medical care and life insurance as well as reduced Social Security and pension payments. ${ }^{22}$ They find that at a discount rate of $5 \%$, the net cost is 15 cents per pack of cigarettes. Both of these studies looked at lifetime costs while our study uses a prevalence approach so that our results cannot be compared with their findings. Data are not available in California to permit us to distinguish the costs that are not internalised by the smoker, but our other work suggests that $43 \%$ of the direct costs are born by public sources. ${ }^{18}$

Cigarette sales in California amounted to $\$ 3.9$ billion in 1993 , compared to $\$ 10.0$ billion for the adverse health costs of smoking. While sales and smoking prevalence are declining over time, it will be many years before the health costs decline because of the cumulative and in many cases irreversible impact of smoking on health.

Because cigarette smoking is known to be the leading preventable cause of illness and premature death, policy makers must continue to push legislation and ordinances that encourage people to quit or to never take up smoking in the first place. Estimates such as those presented in this paper are useful in the discussion of the form these tobacco control policies should take.

This research was supported by funds provided by the Cigarette and Tobacco Surtax Fund of the State of California through the Tobacco-Related Disease Research Program of the University of California.

1 US Department of Health, Education, and Welfare. Smoking and health. Report of the advisory committee to the Surgeon General of the Public Health Service. Washington, DC: Public Health Service, Centers for Disease Control, 1964. (DHHS Publication No (PHS) 1103.)

2 Pierce J, Farkas A, Evans N, Berry C, Choi W, Rosbrook B et al. Tobacco use in California 1992. A focus on preventing uptake in adolescents. Sacramento, CA: California Deuptake in adolescents. Sacramento,

3 Americans for Nonsmokers' Rights. Unpublished data on tobacco control ordinances. Berkeley, CA, 1994.

4 Rice D, Max W. The cost of smoking in California, 1989. Sacramento, CA: California Department of Health Services, 1992.

5 Rice D, Hodgson T, Sinsheimer P, Browner W, Kopstein A. The economic costs of the health effects of smoking, 1984. Milbank Memorial Fund $O$ 1986; 64: 489-547.

6 Kaplan G, Wright W. Health and economic impact of smoking, California, 1985. Sacramento, CA: California Department of Health Services, 1988.

7 US Department of Health and Human Services. Smoking and Health : a national status report. A report to Congress. Rockville, MD: US Public Health Service, 1990. (DHEW Publication No (CDC) 87-8396, Revised 02/90.) (DHEW Publication No (CDC) 87-8396, Revised 02/90.)
California Department of Health Services. Health and economic impact of smoking : California, 1988. Sacramento, CA: California Chronic and Sentinel Diseases Surveillance Program, 1992. (Technical Report No 5.)

9 Rice DP. Estimating the cost of illness. Health Economics Series, No 6. Publication No 947-6. Washington, DC: US Department of Health, Education, and Welfare

10 Rice DP, Hodgson TA, Kopstein AN. The economics of illness: a replication and update. Health Care Financing $\operatorname{Rev} 1985$; 7: 61-80.

11 Schelling TC. The life you save may be your own. In: Chase SB, ed. Problems in public expenditures analysis.

12 Mishan EJ. Cost-benefit analysis. Boston, MA: Unwin Hyman, 1988 .

13 Hodgson TA, Meiners M. Cost-of-illness methodology: a guide to current practices and procedures. Milbank guide to current practices and proce
Memorial Fund $Q$ 1982; 60: 429-62.

14 Robinson JC. Philosophical origins of the economic value of life. Milbank Memorial Fund $Q$ 1986; 64: 133-55.

15 Shultz J, Novotny T, Rice D. SAMMEC II : Computer software and documentation. Atlanta, Georgia: Centers fo Disease Control, Office on Smoking and Health, 1990.

6 Lilienfeld A, Lilienfeld D. Foundations of epidemiology. Oxford: Oxford University Press, 1980

17 US Department of Health and Human Services. Reducing the health consequences of smoking : 25 years of progress. $A$ report of the Surgeos of smoking. 25 years of progress. A report of the Surgeon General, 1989. Atlanta, Georgia Centers for Disease Control, Office on Smoking and 8 Bartlett J, Miller L, Rice D, Max W. Medical care Bartlett J, Miller L, Rice D, Max W. Medical care
expenditures attributable to cigarette smoking - United expenditures attributable to cigarette smoking - United
States, 1993. Morbidity and Mortality Weekly Report 1994; 43(26): 469-72. 
19 Miller TR. Narrowing the plausible range around the value of life. Washington, DC: Urban Institute, 1989.

20 Rice DP, MacKenzie EJ and Associates. The cost of injury in the United States. A report to Congress 1989. San Francisco, CA: Institute for Health and Aging, University of California and Injury Prevention Center, The Johns Hopkins University, 1989.
21 Hodgson TA. Cigarette smoking and lifetime medical expenditures. Milbank $Q$ 1992; 70: 81-125.

22 Manning WJ, Keeler EB, Newhouse JP, Sloss EM, Wasserman J. The taxes of sin. Do smokers and drinkers pay their way? fAMA $1989 ; 261$ : 1604-9. 